could be replicated in Britain for about $£ 50 \mathrm{~m} .^{1}$ The current British system compensates about three people out of every 100000 of the population with an award of $£ 15000$, whereas the Swedish system compensates 10 times as many people with much greater efficiency and an average award of about $£ 3200$.

Now that lawyers and economists are supporting no fault compensation it is surely time for the government to think again-particularly when it ultimately meets most of the costs.

Assistant editor, $B M \mathcal{F}$

RICHARD SMITH

1 Ham C, Dingwall R, Fenn P, Harris D. Medical negligence: compensation and accountability. London: King's Fund Institute, 1988.

\title{
Catching up the orthopods
}

\section{Mechanical forces matter in tissues other than bone}

For almost a century it has been recognised that bone responds to applied mechanical forces with resorption and new bone formation (Wolff's law). ${ }^{1}$ This functional adaptation fashions bone to suit its mechanical environment, endowing optimum strength and stiffness ${ }^{2}$ while keeping its weight and hence metabolic cost to a minimum. Our understanding of this mechanism is incomplete, but its therapeutic implications have been used in treating fractures and in operations to replace joints. ${ }^{34}$ Increasing the mechanical loading on bone increases its formation locally. Conversely, reducing the loading as with immobilisation results in disuse osteoporosis. ${ }^{5}$ More recently the fact that exercise reduces generalised osteoporosis has also been recognised. ${ }^{6}$

Not surprisingly similar effects have been observed in other components of the musculoskeletal system. In articular cartilage moderate physical activity changes the mechanical properties of the tissue. ${ }^{78}$ The tissue biochemistry of the tendons changes rapidly in response to different loads-again implying changes in mechanical behaviour. ' And we now know that this dynamic relation is also important in other connective tissues.

In hypertension arterial smooth muscle cells produce a factor that stimulates fibroblasts to synthesise elastin, which in turn modifies the extensibility of the vessel walls. ${ }^{10}$ When the smooth muscle cells are stretched they synthesise collagen and glycosaminoglycans, which also alter the mechanical behaviour of the tissue. " Endothelial cells respond to shear forces by releasing vasoactive substances that manipulate the contractility of the smooth muscle of the vessel wall. ${ }^{12}$ In the cervix there are gross alterations in tissue microstructure before and during labour..$^{13}$ This is physiological soft tissue remodelling on an enormous scale and is at least partly a response to mechanical stimuli.

Responses to mechanical forces have been reported in other sites including the skin ${ }^{15}$ and lung, ${ }^{16}$ with postulated mechanosensors to account for the changes in blood vessels. ${ }^{12}$ An alternative, or parallel, mechanism may include the transduction of mechanical stimuli into electrical potentials that are then decoded by the cells, a possible explanation for the sensitivity of fibroblasts to applied electrical fields. ${ }^{17} 18$

The importance of mechanical effects in the pathophysiology of many disorders may have been overlooked because we tend to relate all diseases to specific cellular abnormalities. But we need also to consider the interaction between the cells and the tissue matrix on which they depend for their. mechanical support. This has required an increasing awareness of biomechanics. The principles embodied in Wolff's law are no longer confined to orthopaedic conditions. Orthopods are, however, 100 years ahead.

GLYN EVANS Lecturer in Orthopaedics JOHN M EGAN

University of Southampton, Medical Engineer

Faculty of Medicine Orthopaedic Division,

General Hospital,

Southampton SO9 $4 \mathrm{XY}$

Wolff JD. Das Gesetz der Transformation der Knochen. Berlin: Hirschwald, 1892.

2 Lanvon LE. Functional strain in bone tissue as an objective and controlling stimulus for adaptive bone remodelling. I Biomech 1987;20:1083-93.

Perren SM. Physical and biological aspects of fracture healing with specific reference to internal fixation. Clin Orthop 1979;138:175-96.

4 Goodship AE, Kenwright J. The influence of induced micromovement upon the healing of experimental tibial fractures. F Bone foint Surg $[B r]$ 1985;67:650-5.

5 Nilsson BE, Westlin NE. Long term observations on the loss of bone mineral following Colles' fractures. Acta Orthop Scand 1975;46:61-6.

6 Chow R, Harrison JE, Notarius C. Effect of two randomised exercise programmes on bone mass of healthy postmenopausal women. Br Med $\mathcal{F}$ 1987;295:1441-4.

7 Jurvelin J, Kiviranta I, Tammi M, Helminen JH. Softening of canine articular cartilage after immobilisation of the knee joint. Clin Orthop 1986;207:246-52

8 Jurvelin J, Kiviranta I, Tammi M, Helminen JH. Effect of physical exercise on indentation stiffness of articular cartilage in the canine knee. Int $\mathcal{F}$ Sports Med 1986;7:106-10.

9 Gillard GC, Reilly HC, Booth PGB, Flint MH. The influence of mechanical forces on the glycosaminoglycan content of the rabbit flexor digitorum profundus tendon. Connect Tissue Res 1979:7:37-46.

10 Mechan RP, Whitehouse LA, Wrenn DS, et al. Smooth muscle-mediated connective tissue

remodelling in pulmonary hypertension. Science 1987;237:423-6.
11 Leung DYM, Glagov S, Mathews MB. Cyclic stretching stimulates synthesis of matrix components by arterial smooth muscle cells in vitro. Science 1976;191:475-7.
bet

by arterial smooth muscle cells in vitro. Science 1976;191:

12 Lansman JB. Going with the flow. Nature 1988;331:481-2. Danforth DN, Buckingham JC, Roddick JW. C
effacement. Am 7 Obstet Gynecol 1960;80:939-45.

14 Parry DM, Elwood DA. Ultrastructural aspects of cervical softening in sheep. In: Elwood DA, Anderson $\mathrm{ABM}$, eds. The cervix in pregnancy and labour. Edinburgh: Churchill Livingstone, 1981:74-84.

15 Gillard GC, Reilly HC, Booth PGB, Flint MH. A comparison of the glycosaminoglycans of weigh bearing and non-weight bearing human dermis. F Invest Dermatol 1977;69:257-61.

16 Pickup AJ. Collagen and behaviour: a model for progressive debilitation. IRCS Medical Science 1978;6:499-502.

17 Cheng N, Hoof HV, Brockx E, et al. The effects of electric currents on ATP generation, protein synthesis and membrane transport in rat skin. Clin Orthop 1982;171:264-72.

18 McLeod KJ, Lee RC, Ehrlich HP. Frequency dependence of electric field modulation on fibroblast protein synthesis. Science 1987;236:1465-9.

\section{Correction}

\section{Silent myocardial ischaemia}

In the editorial on silent myocardial ischaemia by Dr Stephen Campbell (24 September, $p$ 751) the first sentence of the second paragraph should have read: "Silent ischaemia is defined as 'objective evidence for myocardial ischaemia in the absence of angina or equivalent symptoms,' and its prevalence is unknown, although over a quarter of all myocardial infarctions are unrecognised and a half of those that are unrecognised cause no symptoms at all. ${ }^{. "}$ 